\title{
Kepercayaan Kepada Debata Tiga Batu Tungku Sebagai Pola Kepercayaan Untuk Lebih Memahami Ajaran Allah Tritunggal Yang Kontekstual Di Mamasa
}

\author{
Abialtar \\ Sekolah Tinggi Theologia Indonesia Timur Makassar \\ abialtarpapalan@gmail.com
}

D0I: https://doi.org/10.34307/b.v4i1.185

\begin{abstract}
The author understands that the doctrine of Debata Tiga Batu Tungku system in the To Salu tribe in Mamasa can be an interesting instrument to understand the teaching system or the doctrine of the Trinity God in Christianity. This research found that Debata Tiga Batu Tungku is a symbol of the same presence of God in Christianity for the Mamasa context. First, the author examines the Debata Tiga Batu Tungku belief system and its meaning for the life of the To Salu tribe in Mamasa. Second, the author traces the responses of the evangelists present and brings the teachings of the Triune God into that context. Third, to analyze the Three Furnace Debata teaching system with the perspectives of the relevant theologians. The research method in this paper is qualitative. The author collects the required data through literature studies related to the doctrine of the Trinity, contextual theology and so on. Conducting in-depth observations accompanied by interviews with indigenous parties. The Three Stones Debata Doctrine helps in understanding the contextual and natural teaching of the Triune God. The attributes of God in the Bible are clearly illustrated by the analysis of the doctrinal system in question.
\end{abstract}

Keywords: Triune God, Debata Tiga Batu Tungku To Salu, Mamasa, , Contextual Theology.

Abstrak: Penulis memahami bahwa sistem kepercayaan Debata Tiga Batu Tungku pada suku To Salu di Mamasa dapat menjadi instrumen yang menarik untuk memahami sistem pengajaran atau doktrin Dewa Tritunggal dalam agama Kristen. Penelitian ini menemukan bahwa Debata Tiga Batu Tungku adalah simbol kehadiran Tuhan yang sama dalam agama Kristen untuk konteks Mamasa. Pertama, penulis meneliti sistem kepercayaan Debata Tiga Batu Tungku dan artinya bagi kehidupan suku To Salu di Mamasa. Kedua, penulis menelusuri tanggapan para penginjil yang hadir dan membawa ajaran-ajaran Allah Tritunggal dalam konteks itu. Ketiga, menganalisis sistem pengajaran Debata Tiga Tungku dengan perspektif para teolog yang relevan. Metode penelitian dalam tulisan ini adalah kualitatif. Penulis mengumpulkan data yang dibutuhkan melalui kajian literatur yang berkaitan dengan doktrin Allah Tritunggal, teologi kontekstual dan lain sebagainya. Mengadakan observasi mendalam disertai wawancara dengan pihak pribumi. Doktrin Debata Tiga Batu Tungku membantu dalam memahami ajaran tentang Allah Tritunggal yang kontekstual dan alami. Atribut Allah dalam Alkitab dengan jelas diilustrasikan melalui analisis sistem doktrin yang dimaksud.

Kata kunci: Allah Tritunggal, Debata Tiga Batu Tungku, To Salu, Mamasa, Teologi Kontekstual.

$\begin{array}{llll}\text { Article History : } & \text { Received: 03-07-2020 } & \text { Revised: 31-01-2021 } & \text { Accepted: 25-02-2021 }\end{array}$




\section{Pendahuluan}

Inti tulisan ini adalah upaya menganalisis kepercayaan Debata Tiga Batu Tungku yang dalam bahasa Mamasa disebut Debata Ma'lalikam Tallu. Artinya, Dewa yang hadir pada tiga batu tungku dapur sebagai sebagai salah satu pola mematangkan pemahaman ajaran Allah Tritunggal yang kontekstual. Upaya ini muncul karena To Salu (suatu suku masyarakat di Mamasa) menolak ajaran Allah Tritunggal dari penginjil CGK (de Christelijke Gereformeerde Kerken-Gereja Reformasi Belanda), dan sebaliknya penginjil tersebut menolak ajaran Debata Tiga Batu Tungku yang dianut oleh masyarakat pribumi. Penolakan itu terjadi karena mereka mempertahankan ajarannya masing-masing. To Salu mempertahankan kepercayaan bahwa Debata (Dewa) hadir melalui simbol tiga tungku dapur (ajaran Debata Tiga Batu Tungku). CGK yang diwakili oleh penginjil mereka, Martin Geleijnse mempertahankan kepercayaan bahwa Allah hadir bukan melalui tiga batu tungku tetapi melalui Alkitab yang berbicara mengenai Allah Bapa, Putera, dan Roh Kudus dan diberitakan oleh gereja. ${ }^{1}$ Geleijnse menganggap ajaran To Salu tersebut adalah praktik penyembahan berhala. Sebagai salah satu pola dalam kepercayaan To Salu untuk memantangkan ajaran Tritunggal dalam kekristenan pada masa sekarang maka kepercayaan Debata Tiga Batu Tungku relevan dalam rangka mengakarkan ajaran Alkitab tersebut khususnya dalam konteks To Salu.

\section{Metode Penelitian}

Dalam memahami ajaran Debata Tiga Batu Tungku sebagai ajaran Allah Tritunggal, penulis berpedoman pada model berteologi Stephen B. Bevans, yaitu model teologi kontekstual antropologis yang dikombinasikan dengan model sintesis. Alasan penulis berpedoman pada kedua model berteologi tersebut adalah karena model pertama mengindahkan manusia dan kebudayaannya dan model kedua mengindahkan dialog antara dua teologi yang sumber dan latar belakang masing-masing berbeda. ${ }^{2}$

Metode penelitian dalam tulisan ini adalah kualitatif. Penulis mengumpulkan data yang dibutuhkan melalui kajian literatur yang berkaitan dengan doktrin Allah Tritunggal, teologi kontekstual dan lain sebagainya. Untuk mengetahui ajaran Debata Tiga Batu Tungku, penulis mengadakan observasi mendalam disertai wawancara dengan pihak pribumi. Selain itu penulis juga memeriksa berbagai tulisan para tokoh pribumi yang ada. Data yang ditemukan dianalisa dengan mengombinasikan model antropologis dengan model sintesis tersebut. Perlu ada dialog antara keduanya dengan metode hermeneutik kontekstual.

\footnotetext{
${ }^{1}$ P. Pappalan, “Ajaran Allah Tritunggal Geleijnse," Pembinaan Majelis Gereja Jemaat Saludengen (Mambi, 1969).

${ }^{2}$ Stephen B Bevans, Models of Contextual Theology, Revised and Expanded Edition (New York: Orbis Books, 2002).
} 


\section{Hasil dan Pembahasan}

\section{Pentingnya Teologi Kontekstual untuk Memahami Ajaran Allah Tritunggal}

Dalam sejarah, manusia senantiasa berusaha membahasakan Allah yang tak terbatas.Thomas Aquinas (1225-1274), misalnya, menggunakan pendekatan katafatik dengan mengatakan bahwa mengetahui Allah yang tak terbatas tetapi dapat dihampiri.dikelan itu harus melalui “jejak-Nya”, yaitu "efek Allah di dunia ini”. ${ }^{3}$ Jejak atau efek Allah di dunia ini adalah ciptaan-Nya, termasuk manusia dan kebudayaannya. Oleh karena itu, tidak ada ciptaan yang tidak menggambarkan penciptanya. Pandangan ini disebut sebagai "penyataan umum Allah." Oleh karena itu, Banawiratma benar ketika berkata bahwa alam merupakan sacramentum (tanda-tanda) dari kehadiran Yang Ilahi, yang dialami melalui bentuk-bentuk dan unsur-unsur tertentu. ${ }^{4}$ Pengutusan Putra (Yesus) dan inkarnasi-Nya memungkinkan sang asing, termasuk manusia yang jatuh ke dalam dosa, mengambil bagian dalam karya Allah Tritunggal.

Hal tersebut di atas ada hubungannya dengan teologi kontekstual atau inkulturasi dalam Katolik, yang berhubungan dengan masalah pengindahan dan pemanfaatan kebudayaan setempat yang tradisional sebagai sarana untuk "mendekati" Allah yang adalah misteri. Dalam kontekstualisasi, manusia berhadapan dengan konteks kebudayaan dan agama yang tradisional di satu pihak, tetapi di pihak lain bergumul juga dengan konteks modernisasi yang menyebabkan perubahan-perubahan nilai, khususnya sehubungan dengan martabat manusia. ${ }^{5}$ Kontekstualisasi bukan usaha memisahkan persaudaraan universal di antara orang-orang beriman, melainkan satu sama lain belajar dari kekayaan masing-masing, bebas dari paksaan atau keharusan menerima satu pandangan sebagai "kebenaran Injil."6

Walaupun demikian, tetap harus diantisipasi bahaya arkhaisme dan juga modernisme. Singgih berkata:

Yang pertama mengagung-agungkan masa lalu yang tidak pernah kembali, sebagai pelarian dari tantangan-tantangan masa kini atau komersialisasi budaya, termasuk komersialisasi budaya dari pihak pemerintah. Yang kedua meremehkan atau mengabaikan tradisi dan menganggap pemelukan suatu kebudayaan modern (baca:

Barat) sebagai tanda bahwa ia selamat, sedangkan tradisi dianggap sebagai keberdosaan. ${ }^{7}$ Yang baik adalah "pengakaran" teologi dari kebudayaan" dalam rangka menghargai martabat atau harga diri manusia. Kontekstualisasi gereja berarti lebih menonjolkan kekayaan yang ada pada diri kita sendiri sebagai tanda kedewasaan Gereja setempat yang sempat sangat berwarna Barat, sedangkan segi Indonesianya menjadi kabur. Ada juga bahaya lain yaitu xenophobia, yaitu kontekstualisasi yang salah kaprah karena bersikap

${ }^{3}$ Ellen T Armour and et.al, "God," in Constructive Theology, ed. Serene Jones and Paul Lakeland (Minneapolis: Fortress Press, 2005), 34.

${ }^{4}$ J.B Banawiratma, Agenda Pastoral Transformatif (Yogyakarta: Kanisius, 2002), 27.

${ }^{5}$ Emanuel Gerrit Singgih, Berteologi Dalam Konteks: Pemikiran-Pemikiran Mengenai Kontekstualisasi Di Indonesia (Yogyakarta: Kanisius, 2000), 23.

${ }^{6}$ Ibid, 25.

${ }^{7}$ Ibid. 
anti Barat. ${ }^{8}$ Xenophobia dijelaskan sebagai "a fear of foreigners or strangers". ${ }^{9}$ Xenophobia juga diartikan sebagai ketakutan irasional terhadap orang asing ataupun hal-hal asing.

Alkitab pun mempunyai konteks, sehingga Allah memperkenalkan diri dan karyaNya melalui proses pergumulan orang dalam konteks di mana ia berada dan menulis teks Alkitab. Konteks sangat berperan. Oleh karena pengaruh konteks, persepsi mengenai kehadiran Allah dalam Perjanjian Lama dan penekanan antara iman dan perbuatan dalam Perjanjian Baru memperlihatkan adanya perbedaan. Singgih memberi contoh sebagai merujuk Mazmur 139 yang menampakkan hiburan yang dialami oleh orang beriman akibat keyakin-annya bahwa Allah hadir di mana-mana. Sedangkan Mazmur 39 menunjukkan bahwa ada juga orang yang merasa tersiksa karena Allah hadir terusmenerus.

Dalam Alkitab Perjanjian Baru, Rasul Paulus memakai dupa atau kemenyan yang berbau harum untuk menggambarkan persembahan kepada Kristus. Sudah bisa dipastikan bahwa dupa atau kemenyan adalah salah satu bahan penting dalam penyembahan kepada dewa-dewi zaman itu. Dalam pemberitaan Injil, Paulus pun menunjuk kepada mezbah penyembahan orang-orang Atena kepada dewa-dewa, yaitu mezbah dengan tulisan: "Kepada Allah yang tidak dikenal" (Kis. 17:23), untuk memperkenalkan Kristus. Oleh karena itu, pemakaian simbol dalam konteks tertentu demi pemahaman iman dan pemberitaan Injil adalah hal yang biasa dan penting. ${ }^{10}$

Selain pendapat Singgih, pendapat Bevans sangat penting dipaparkan di sini. Menurut Bevans, ${ }^{11}$ "Teologi kontekstual adalah sebuah cara berteologi yang di dalamnya seseorang mengindahkan roh dan pewartaan Injil; tradisi orang Kristen; kebudayaan di mana ia sedang berteologi; dan perubahan sosial di dalam kebudayaan itu, entah yang dihasilkan oleh proses teknologi Barat atau perjuangan akar rumput demi persamaan, keadilan, dan pemerdekaan."

Menurut penulis, model teologi kontekstual Bevans yang cocok diterapkan di Toraja Mamasa adalah model antropologis dalam dua arti. Yang pertama, model ini berpusat pada nilai dan kebaikan anthropos, pribadi manusia (centers on the value and goodness of anthropos, the human person). ${ }^{12}$ Pengalaman manusia, yang dibatasi namun juga serentak terpenuhi dalam kebudayaan, perubahan sosial, serta lingkungan geografis dan historis, dipandang sebagai kriteria penilaian yang mendasar yang menyangkut apakah satu pengungkapan kontekstual tertentu terbilang sejati atau tidak. Yang kedua, model ini berusaha memahami secara lebih jelas jaringan relasi manusia serta nilai-nilai

\footnotetext{
${ }^{8}$ Ibid, 24.

${ }^{9}$ ArtiKata.com, "Word Definitions," http://www.artikata.com/arti-205593-xenophobia.html

${ }^{10}$ Singgih, Berteologi Dalam Konteks: Pemikiran-Pemikiran Mengenai Kontekstualisasi Di Indonesia.

${ }^{11}$ Bevans, Models of Contextual Theology, Reivsed and Expanded Edition, 56.

12 Ibid.
} (diakses 25 Februari 2020). 
yang membentuk kebudayaan manusia, dan di dalamnya Allah hadir, menawarkan kehidupan, penyembuhan serta keutuhan (tries to undertand more clearly the web of human relationship and meanings that make up human culture and in which God is present, offering life, healing, and wholeness). ${ }^{13}$ Jadi, penekanan utama model atau pendekatan ini adalah kebudayaan. ${ }^{14}$ Jadi, masalahnya bukan menyangkut isi Injil atau Allah itu sendiri, melainkan mengenai bentuk khas mengenai persepsi pengenalan Allah melalui simbolsimbol dan gambaran-gambaran yang bermakna dalam keterbatasan waktu dan ruang manusia. ${ }^{15}$

Pemaknaan simbol atau lambang tertentu dalam suatu komunitas dalam rangka merumuskan teologi yang kontekstual tertentu, didukung juga oleh Karl Barth. Barth menganjurkan agar para ahli teologi Amerika mengembangkan suatu teologi kemerdekaan. Ketika mengunjungi Amerika Serikat pada tahun 1962, ia berkata: "Patung kemerdekaan yang berdiri di pelabuhan New York pun bisa menjadi lambang atau simbol teologi kemerdekaan, asal saja dibebaskan dari bayangan ideologis dan mitis." ${ }^{16}$ Barth menambahkan bahwa "suatu teologi yang demikian dapat membebaskan orang-orang Kristen Amerika dari perasaan rendah diri terhadap orang-orang Eropa dan perasaan tinggi hati terhadap orang-orang Asia dan Afrika". ${ }^{17}$

Selain model teologi kontekstual antropologis, juga model teologi sintesis dari Bevans akan dipakai dalam memahami ajaran Debata Tiga Batu Tungku sebagai ajaran Allah Tritunggal. Jadi, penulis mengombinasikan dua model teologi kontekstual tersebut di atas. Menurut Bevans, model sintesis adalah sebuah model jalan tengah (a middle-ofthe road model). ${ }^{18}$ Jalan tengah akan diusahakan dengan pemahaman bahwa Debata Tiga Batu Tungku dan Allah Tritunggal saling melengkapi, karena keduanya mempunyai kelemahan. Maksud penulis "kelemahan" ajaran Allah Tritunggal adalah pemahaman terhadap ajaran tersebut yang dirumuskan oleh teolog tertentu seperti Trinitas Modalisme dan Subordinatif. Sejalan dengan itu, Bevans berkata:

Model sintetik ini dalam pengertian Hegelian, tidak hanya mencoba untuk menyatukan segala sesuatunya dalam semacam kompromi tetapi mengembangkan, dalam dialektika kreatif, sesuatu yang dapat diterima oleh semua sudut pandang. Oleh karena itu, nama lain untuk model ini mungkin adalah "model dialektis". Atau karena model ini melibatkan dialog terus-menerus dan penggunaan apa yang oleh David Tracy dinamai imajinasi anologis, model tersebut mungkin juga disebut sebagai "model dialogis", "model percakapan", atau bahkan "model analogis. ${ }^{19}$

Oleh karena baik ajaran Allah Tritunggal yang diwartakan oleh Geleijnse maupun Debata Tiga Batu Tungku sama-sama diindahkan, maka penulis mengombinasikan model

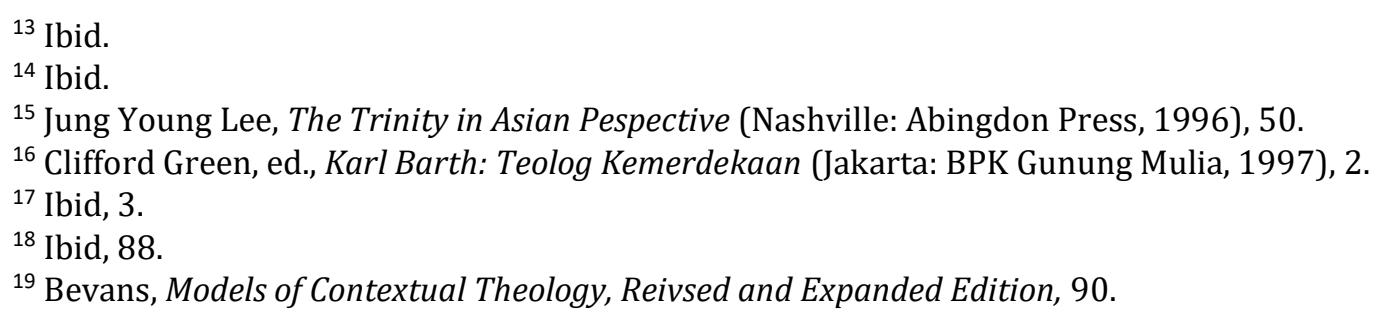


antropologis dengan model sintesis tersebut. Penulis melihat bahwa baik Allah Tritunggal yang diwartakan oleh gereja Barat (baca: Geleijnse) maupun Debata Tiga Batu Tungku yang diwariskan oleh To Salu merupakan anugerah penyataan Allah untuk mengenal diri dan pekerjaan-Nya. Perlu ada dialog antara keduanya.

Orang asing tersebut di atas dianggap tidak percaya kepada Debata Tiga Batu Tungku sehingga To Salu menerima mereka dengan ma'sara' (kebiasaan To Salu menawarkan sesuatu pemberian kepada sesamanya sebagai penghargaan) Ma'sara' itu diajarkan oleh Debata Tiga Batu Tungku, yaitu bahwa orang asing diterima, tetapi jika mereka membawa ajaran yang berbeda dengan ajaran Debata tersebut maka mereka tidak akan diterima dengan sepenuh hati. ${ }^{20}$ Akan tetapi To Salu memperhatikan orang asing dengan mantila' (memberi atau membagi daging atau makanan lainnya kepada orang lain atau orang asing).

\section{Ajaran Debata Tiga Batu Tungku}

To Salu di daerah Mamasa mendasarkan kehidupan mereka pada ajaran Alu' Todolo. Alu' Todolo mengajarkan Pemali Appa Randanna atau empat aturan dasar Debata, yang harus dipatuhi. Tujuan To Salu mematuhi dan melaksanakan ritus Pemali Appa Randanna adalah untuk menyembah Debata Tiga Batu Tungku dan memperoleh berkat dari Debata itu. Debata akan menjumpai dan memberkati To Salu yang melaksanakan ritus Pemali Appa Randanna tersebut dengan baik. ${ }^{21}$

Dalam ajaran Debata Tiga Batu Tungku, orang asing disebut to ta'diita rambu apinna (orang yang jauh dan berasal dari tempat jauh atau luar negeri), to bulim (orang sesat), to ta'diadai (orang yang tidak mempunyai kepercayaan atau agama), to mangnganga' (orang yang datang dari daerah lain pada musim panen untuk mencari makanan), dan sabua' (hamba yang dibeli dari daerah lain). ${ }^{22}$

Alu' Todolo mengajarkan secara turun-temurun bahwa Debata bisa memanifestasikan diri dan tindakan atau karyanya dengan menempati berbagai macam benda di dunia ini. ${ }^{23}$ Debata bisa memakai sarana apa saja dan di mana saja untuk menghadirkan diri-Nya dengan tetap memperhitungkan dan atau mempertimbangkan kemampuan manusia. ${ }^{24}$

Debata atau Dewata dapat hadir di bagian-bagian dalam rumah yang telah ditetapkan oleh imam Alu' Todolo. Debata dipercaya hadir di tempat yang dianggap sebagai wadah Debata memberi berkat kepada umat-Nya, misalnya di dapur. ${ }^{25}$ Dalam

\footnotetext{
${ }^{20}$ Ibid.

${ }^{21}$ P. Pappalan, “Ada' Tomalillim,” Ceramah GTM-Klasis Bambang Hulu (Mamasa, 1976).

${ }^{22}$ P. Pappalan, "To Pusa: To Bulim Anna To Mangnganga," Pembinaan GTM Klasis Malatiro (Mamasa, 1999).

${ }^{23}$ Ibid.

${ }^{24}$ Ibid, 6.

${ }^{25}$ Sando Patu', “Wawancara Oleh Penulis, Salutabang," 2014.
} 
kehidupan masyarakat suku Toraja Mamasa, dapur dengan tiga batu tungkunya, lalikam, memiliki arti yang penting. Bongkahan batu itu menjadi simbol untuk para dewa (Debata). ${ }^{26}$ Batu pertama menyimbolkan kehadiran Debata To Metampa (Allah Pencipta), batu kedua menyimbolkan kehadiran Debata To Mepasalama' atau To Memana' (Allah Penyelamat) dan batu ketiga menyimbolkan kehadiran Debata To Meolaam (Allah Penyerta).

Debata Tiga Batu Tungku diyakini memberi berkat dan berkat itu dapat dilihat, dirasakan, dibicarakan, dan disaksikan oleh orang lain. Berkat tersebut bagi To Salu dilihat, dirasakan, dan disaksikan oleh anggota keluarga di dapo' (dapur), karena di situ makanan dapat dilihat dan dinikmati bersama, bahkan dapat mantila', yaitu membagi atau memberi daging atau makanan lainnya kepada orang lain atau orang asing. ${ }^{27}$ Jadi, kepercayaan kepada Debata menekankan tindakan dan intervensinya kepada manusia.

Kesatuan Debata To Metampa, Debata To Memana' atau To Mepasalama', dan Debata To Meolaam disimbolkan juga oleh tungku dapur yang ditanam dengan posisi melingkar. Pabolla berkata posisi tungku dapur yang melingkar dan ketiga batu menunduk ke dalam menunjukkan kasiolaam Debata ilam panggandakan (keesaan Tuhan dalam tarian). Makin lama makin menyatu tanpa ada yang terlepas seperti juga air yang ditanak di atas dapur yang jika telah mendidih akan bergelembung dan gelembunggelembung itu sikore (menyatu), baik dari fisiknya maupun uap yang ditimbulkan, maupun bunyi air yang mendidih tersebut. ${ }^{28}$

Pada waktu para ibu rumah tangga (to ma'dapo') memasak daging maka mereka wajib menyisihkan sedikit daging tersebut sebagai taba Debata (bagian Debata). Bagian tersebut dikhususkan dan dibakar habis di tengah-tengah tungku. Salah satu alasan Geleijnse menganggap ajaran Debata Tiga Batu Tungku sebagai praktik penyembahan berhala adalah anggapan bahwa To Salu menyembah batu. ${ }^{29}$ Selain itu ada juga taba poppa' (bagian roh jahat), yaitu potongan daging kecil yang dibuang oleh ibu rumah tangga dari arah dapur ke sebelah barat. Diyakini bahwa Debata Kadake (dewa jahat) selalu ingin mengganggu penyembahan kepada Debata Pencipta, Penyelamat dan Pemelihara. Oleh karena itu, mereka ditenangkan dengan memberikan bagian mereka.

Perlu dijelaskan bahwa To Salu tidak menyembah batu, karena bagi mereka tiga batu tungku itu bukan Debata, melainkan simbol kehadiran Tiga Debata yang kemudian disebut Debata Tiga Batu Tungku. Pengertian dari larangan mematungkan Allah adalah Allah tidak menghendaki apabila manusia menguasai diri-Nya dalam satu rupa atau konsep, penafsiran atau ajaran. ${ }^{30}$

\footnotetext{
${ }^{26}$ Kees Buijs, Powers of Blessing From The Wilderness and From Heaven: Structure and Transformation in The Religion of The Toraja in Mamasa Area of South Sulawesi (Leiden: KITLV Press, 2006), 120.

27 Ibid.

${ }^{28}$ Pabolla, "Wawancara Oleh Penulis, Mamasa," 7 April, 2015.

${ }^{29}$ Pappalan, "Ada' Tomalillim."

${ }^{30}$ C Barth, Theologia Perjanjian Lama 1 (Jakarta: BPK Gunung Mulia, 1970), 254.
} 
Dalam kekristenan, percakapan tentang Allah berangkat dari kenyataan bahwa Allah itu adalah misteri tetapi juga pribadi yang memperkenalkan diri. Ia memperkenalkan diri-Nya dengan mempertimbangkan kemampuan manusia. ${ }^{31}$ Oleh karena itu, pribadi Allah dikenal dalam Yesus Kristus. Ada keberatan atas hal ini, yaitu bahwa menggambarkan Allah sebagai suatu pribadi atau seseorang dapat berarti menurunkan Allah dari ketinggian-Nya untuk tiba pada level pemikiran kita ${ }^{32}$ atau kebudayaan dan realitas manusia.

Paul Tillich, misalnya, yang dikutip oleh Nuban Timo, berbicara tentang difficulties of location ketika menggambarkan Allah sebagai seseorang seperti manusia. Tillich menolak percakapan tentang Allah dalam pengertian personal, sebab Allah tidak dapat disamakan dengan satu pribadi. ${ }^{33}$ Bagi Nuban Timo, upaya menggambarkan Allah sebagai satu pribadi tidaklah bermaksud menyamakan Allah dengan manusia atau menempatkan Allah pada satu tempat tertentu di alam, melainkan untuk menegaskan kesediaan dan kemampuan Allah untuk berelasi dengan yang lain yang secara kualitatif berbeda dengan diri-Nya

Jika Allah mempertimbangkan kemampuan To Salu mengambil cara untuk menghadirkan diri-Nya melalui tiga batu tungku maka hal itu bukan mematungkan Allah atau penyembahan berhala. Penulis setuju dengan Nuban Timo bahwa "Allah tidak habishabisnya memperkenalkan diri-Nya". ${ }^{34}$ Di tempat atau konteks mana dan dengan cara bagaimana Allah menyatakan diri-Nya, ditentukan oleh Allah itu sendiri. Tetapi dengan penjelasan di atas bukan berarti bahwa kritikan Geleijnse ditolak secara total, karena dalam masyarakat To Salu dan juga Toraja Mamasa sampai pada tahun 1960-an ada batu jimat yang dipercaya sebagai sarana menampung kuasa Debata Kadake (Iblis). Batu jimat itu disebut juga batu doti (jimat untuk menghipnotis orang lain dan juga binatang peliharaan) dan batu kak'ba (jimat kekebalan dari barang tajam). Itu dapat dipakai mencelakakan orang lain dalam bentuk memenggal kepala orang asing, mengawini perempuan dengan paksa, mencuri binatang peliharaan orang lain, dan sebagainya. ${ }^{35}$ Dalam praktiknya seseorang dapat memakai boneka sebagai bentuk wajah dan tubuh dari korban (misalnya perempuan yang akan dikawini paksa pelaku). Boneka akan diperlakukan sedemikian rupa sehingga roh sang perempuan "melayang" menghampiri pelaku dan pada akhirnya menimbulkan kerinduan luar biasa dari korban untuk bertemu dan kawin dengan pelaku. ${ }^{36}$

${ }^{31}$ Ebenhaizer I. Nuban Timo, Allah Yang Mengulang Diri-Nya Tiga Kali: Suatu Pertimbangan Bagi Dogmatika Kontekstual Indonesia (Salatiga: Satya Wacana University Press, 2013), 118.

${ }^{32}$ Ibid.

${ }^{33}$ Ibid, 120.

34 Ibid.

35 Jidon Matanga', “Doti Dan Kekristenan,” Pembinaan PPGTM Klasis Makassar (Makassar, 1988).

${ }^{36}$ Ibid. 


\section{Ajaran Allah Tritunggal Perspektif Tiga Batu Tungku}

Menurut Nuban Timo, ada lima atribut dan salah satunya adalah "Allah membaui". Dalam Alkitab diceritakan bahwa ketika Tuhan mencium persembahan yang harum Nuh, maka Ia berjanji takkan mengutuk bumi ini (bd Kej 8:20-21). Bau seperti itu menunjuk kepada karya pendamaian dalam Kristus. Paulus menulis itu demikian (2 Korintus 2:14-15): “tetapi syukur kepada Allah yang dalam Kristus selalu membawa kami di jalan kemenangan-Nya. Dengan perantaraan kami Ia menyebarkan keharum-an pengenalan akan Dia di mana-mana. Sebab bagi Allah kami adalah bau yang harum dari Kristus di tengah-tengah mereka yang diselamatkan dan di antara mereka yang binasa. ${ }^{37}$

Salah satu aturan pali' tomate adalah kewajiban anak-anak si mati menyediakan hewan kurban untuk disembelih pada upacara pemakaman orangtua mereka. Pada saat itu terjadilah persekutuan To Salu yang disebut ma'mesa-mesa, ma'tula-tula' (bersatu dan berdialog - telah dijelaskan di Bab Dua). Seluruh masyarakat To Salu berhimpun di sekeliling rumah keluarga dari si mati dan mereka memperbincangkan kehidupan si mati tadi tetapi juga hal-hal lain yang berhubungan dengan situasi masyarakat To Salu. Dalam konteks ma'mesa-mesa ma' tula-tula', masyarakat To Salu makan daging bersama tetapi mereka tetap melaksanakan mantila' tersebut kepada orang lain atau tamu yang diketahui kehadirannya oleh panitia pemakaman. Bahkan orang asing yang datang dalam ritual tersebut masih diberi daging untuk dibawa pulang ke kampungnya. ${ }^{38}$

Mantila' diberlakukan juga bagi tetangga terdekat dan juga bagi mereka yang sudah lama menetap di lingkungan di mana rumah tangga tersebut mempunyai daging atau makanan lainnya walaupun di luar konteks upacara kematian. Apakah Debata yang disembah itu memang hanya memilih orang "dalam" saja yang dikasihi? Menurut Pabolla, seorang tokoh masyarakat di PUS, Debata To Metampa dan To Meolaam mempunyai karakter kasih yang universal, karena Debata itu menciptakan seluruh manusia dan alam semesta beserta isinya dan juga memelihara ciptaan tersebut. Berbeda dengan Debata To Metampa dan Debata To Meolaam, Debata To Mepasalama' atau To Memana' mempunyai karakter lain, yaitu memana' (memberi warisan) hanya kepada mereka yang dianggap "anak".

Status "anak" yang menerima mana' (warisan) dalam pandangan kepercayaan To Salu adalah masyarakat yang dekat dan berada pada garis keturunan dengan nenek moyang To Salu dan mereka yang sudah lama menetap di daerah tersebut setelah memenuhi persyaratan ritual tertentu. Jadi, pada mulanya, tila' (daging atau makanan) tidak diperuntukkan bagi orang asing termasuk mereka yang baru datang dari tempat atau daerah lain. Tetapi karena pemahaman bahwa Debata Tiga Batu Tungku itu sakutu'

\footnotetext{
${ }^{37}$ Ibid, 193-194.

38 Ibid.
} 
(satu dalam keberadaan dan tindakan) maka Debata To Mepasalama' atau To Memana' juga mengajarkan mantila' kepada orang asing.

Pada mulanya, To Salu memahami bahwa Debata Tomemana' atau Debata To Mepasalama' lebih mengasihi orang pribumi dengan segenap hati; orang asing hanya dihargai, tetapi kasih kepada mereka tidak dinyatakan dengan segenap hati. Apul menjelaskan karakter eksklusivitas To Salu tersebut dan hubungannya dengan mantila' sebagai berikut:

Perjumpaan Debata To Mepasalama' atau To Memana' dengan To Salu menyebab-kan mereka mengklaim diri sebagai orang-orang yang diistimewakan dibandingkan dengan orang yang jauh (baca: asing). Dalam Alu' Todolo diwariskan ajaran yang menekankan pentingnya mana' (warisan) dari orangtua kepada anak yang sah dan juga dekat dengan mereka (orangtua tersebut). Warisan itu bisa berupa sawah, kerbau, kebun, dll. Dalam struktur masyarakat To Salu, anak kandung harus mendapat bagian harta warisan yang akan menjadi tanggung jawab mereka untuk mengelolanya dan sekaligus pengikat agar tidak meninggalkan daerah atau kampung nenek moyang yaitu PUS. Anak tiri (baca: orang asing) perlu juga dikasihi dan dihormati, tetapi tidak seperti dengan anak kandung (baca: orang lama atau pribumi). Mereka, bagaimana pun, adalah orang asing, ta' diita rambu apinna (tidak kelihatan asap api dapur mereka dari rumah mereka). Oleh karena itu, mereka harus melakukan ritual khusus untuk dapat masuk dalam pemeliharaan Debata To Mepalasama' atau To Memana'. Dan sebelum ritual khusus itu dilaksanakan, Debata Tiga Batu Tungku harus bersatu (sakutu') dalam pengajaran dan perhatian kepada manusia. Oleh karena Debata Tiga Batu Tungku mengajarkan mantila' tersebut. ${ }^{39}$

Ada dua aspek penting dalam kepercayaan To Salu pada Debata Tiga Batu Tungku yang dijelaskan di atas. Yang pertama, pemahaman kesatuan dan relasi Debata To Metampa, Debata To Mepasalama' atau Debata To Memana', dan Debata To Meolaam. Yang kedua, Debata Tiga Batu Tungku adalah Debata yang mendatangi dan menyelamatkan To Salu. Debata Tiga Batu Tungku rela menempati benda berupa batu dan diam dalam pusat kehidupan To Salu (dapo', dapur). Bukan itu saja, Debata To Mepasalama'atau To Memana' "menyelamatkan" To Salu dan juga orang asing dengan mengajarkan ritual khusus keselamatan.

Dua aspek penting itulah yang dipertahankan oleh To Salu sehingga tercipta-lah praktik penerimaan mereka terhadap orang asing. Aspek itu pulalah yang akan menjadi acuan penulis dalam bagian berikut, yaitu analisis atas temuan-temuan dalam tulisan ini dalam rangka menguji kepercayaan Debata Tiga Batu Tungku dari perspektif kombinasi dua model teologi kontekstual, yakni model antropologis dan sintesis yang dijelaskan di atas untuk memahami ajaran Allah Tritunggal. Selain itu, sumbangan pemikiran beberapa teolog sistematika yang membahas ajaran Allah Tritunggal yang juga telah disebutkan di atas juga sangat penting.

\section{Relasi Persekutuan Debata dan Persekutuan Tritunggal}

${ }^{39}$ Apul, “Debata Tomemana,” Ceramah PPGTM Klasis Bambang Hilir (Mambi, 1999). 
Menurut penulis, Debata yang hadir melalui simbol tiga batu tungku di dapur To Salu juga memiliki struktur trinitarian seperti dalam ajaran Allah Tritunggal. Demikian pula dengan kesatuan Debata Tiga Batu Tungku. Kesatuan Debata itu disimbolkan dengan tiga batu tungku yang berdiri di wadah dapur. Tiga batu itu bekerjasama menahan wadah masakan yang ada di atas ketiga batu. Masakan yang di atas tiga batu tungku akan tumpah jika ada satu batu terguling. Jika satu batu tungku dikeluarkan maka itu bukan lagi tungku, karena tungku dalam konteks To Salu artinya tiga batu yang ditancapkan bersamaan dan diawali dengan upacara yang sama (ritual mebatu).

Karena semua batu tungku hadir bersamaan dan dengan ritual yang sama maka tidak ada subordinasi, tidak ada yang sebelum dan sesudah, tidak ada yang pertama, kedua dan ketiga, tidak ada dominasi dan marjinalisasi. Dengan relasi dan persekutuan seperti itu, maka mereka sangat solid memberi berkat kepada To Salu. Pappalan berkata:

Debata Tiga Batu Tungku adalah Sungnga' (pribadi-pribadi) yang berperan sesuai kebutuhan To Salu, tetapi asal mereka sama yaitu Salu Mariri (Surga) dan disapa secara singkat dengan Puang Ala Ta Alah Matua (Allah di atas segala Allah yang Tua) karena di antara pribadi tidak ada yang lebih tua atau lebih muda, lebih besar atau kecil. Batu tungku diambil dari tempat yang sama dan ukuran yang sama pula. Mereka hadir pun secara bersamaan karena ritual mebatu dilaksanakan sikore (serentak).Walaupun peranan tiap Sungnga' berbeda karena kebutuhan manusia yang beragam, tetapi mereka tetap pada mesa kada dipotuo pantang kada di pomate (bersatu akan teguh dan bercerai akan mati). Itulah sebabnya To Salu selalu mengedepankan persatuan. Batu tungku itu sipengngundui (saling menghormati) sehingga mereka bisa bekerjasama memberi berkat kepada kita yang menomba (percaya). ${ }^{40}$

Hal pertama yang penting dari relasi di antara Debata menurut Pappalan adalah kesatuan asali, kesatuan hakikat, dan juga kuasa tanpa ada dominasi di antara pribadi. Relasi semacam itu dapat menolong To Salu memahami dan mengimani ajaran Allah Tritunggal. Hal itu penting, karena dalam perjalanan sejarah, teolog abad mula-mula seperti Origenes, dan juga Arius, berusaha mengungkapkan hakikat Allah dengan berkata bahwa Allah Bapa lebih besar dari Putra, yang pada gilirannya lebih besar daripada Roh Kudus. Arius menambahkan bahwa Putra itu hanya ciptaan dari yang tidak ada, bukan Allah. ${ }^{41}$

Hal kedua, relasi antara Debata To Metampa, Debata To Mepasalama' atau To Memana' dan To Meolaam adalah suatu persekutuan yang saling membutuhkan, sehingga mereka digambarkan dengan simbol batu tungku yang saling menghormati (sipengngundui) dalam sikap kerendahan hati dan saling mengakui. Relasi demikian merupakan kualitas keilahian melalui ikatan kuat dan teguh. Karena saling membutuhkan maka salah satu dari ketiga pribadi tersebut tidak dapat dieliminasi untuk tujuan tertentu. Ketiganya berbagi dalam satu esensi ilahi yang sama.

Arius terjebak ke dalam subordinasi sehingga memunculkan pendapat bahwa ada yang lebih tinggi daripada yang lain, ataupun terdapat perbedaan kualitas keilahian.

\footnotetext{
${ }^{40}$ Yuliance, "Wawancara Oleh Penulis, Rantelemo," 12 Juni 2018.

${ }^{41}$ Tony Lane, Runtut Pijar: Sejarah Pemikiran Kristiani (Jakarta: BPK Gunung Mulia, 1993), 55.
} 
Menurut penulis, pandangan Arius tersebut merupakan contoh dari dampak subordinasi dan modalisme dalam memahami Allah Tritunggal yang tidak sesuai dengan pandangan Alkitab dan merupakan pemahaman yang salah. Ajaran trinitas modalisme, misalnya oleh Sabelius (kira-kira tahun 200). Ia sangat kuat memberi tekanan pada keesaan Allah, tetapi akibatnya kebhinekaan pribadi Allah dikorbankan. Sebelius mengajarkan bahwa Allah yang satu itu hadir dalam sejarah bukan hanya dalam pribadi yang berbeda tetapi juga dalam rentang waktu yang tidak sama. ${ }^{42}$

Dalam ajaran Allah Tritunggal, Putra (Yesus Kristus) menyelamatkan orang Yahudi dan non-Yahudi. Gereja, dengan berpedoman pada teks Alkitab tertentu, menyelenggarakan ritual yang disebut Baptisan sebagai tanda masuk Kristen. Tetapi apa yang Putra kerjakan adalah pekerjaan Bapa dan Roh Kudus. Alkitab menyaksikan bahwa perbedaan antara Allah Bapa, Putra, dan Roh Kudus bukan sekadar masalah kejamakan peran dalam Allah. Itu terlihat umpamanya dalam peristiwa baptisan Yesus di Yordan (Mat. 3:16-17). Yang terjadi adalah kehadiran tiga pribadi Allah secara serentak bersamasama. Ini jelas bertentangan dengan penjelasan modalitas yang membedakan tiga cara berada Allah dalam waktu yang berbeda. ${ }^{43}$

Demikian juga dengan ajaran Allah Tritunggal subordinatif yang dikembang-kan oleh Arius (meninggal tahun 336) dan Eusebius. "Disebut subordinatif karena ketiga pribadi ilahi yang disaksikan Alkitab digambarkan sebagai yang memiliki kadar keilahian. Allah Sang Bapa memiliki kadar keilahian yang lebih tinggi dari Anak dan Roh Kudus". ${ }^{44}$ Jadi, Sang Bapa sajalah yang benar-benar Allah dan tidak setara dengan Sang Anak karena Sang Anak dibentuk oleh Sang Bapa sebelum permulaan waktu. Ajaran semacam ini ditolak oleh gereja karena "lebih suka memilih prinsip thinking before atau outside revelation". ${ }^{45}$ Dengan jelas Alkitab menegaskan adanya kesatuan substansi antara Sang Bapa dan Sang Anak (bnd. Yoh. 1:1; 14:9).

Ajaran Modalisme dan Subordinatif tersebut muncul karena gereja menghadapi tantangan monoteisme Yahudi dan politeisme Yunani dan Roma. Permasalahan tersebut kemudian disikapi oleh berbagai konsili, di antaranya konsili Nicea 325 dan Konstantinopel 381 yang hasilnya tetap diterima sebagai kebenaran sampai sekarang. Meski demikian, upaya untuk merefleksikan ketritunggalan Allah tetap berlanjut sampai sekarang ini, sehingga selalu terbuka kemungkinan adanya reinterpretasi terhadap ajaran tersebut.

Perspektif dari teolog sistematika, seperti dikemukakan Neil Francis Pembroke dan Catherine Mowry LaCugna, menerangi relasi tersebut. Menurut Pembroke, kesatuan

${ }^{42}$ Timo, Allah Yang Mengulang Diri-Nya Tiga Kali: Suatu Pertimbangan Bagi Dogmatika Kontekstual Indonesia, 120.

${ }^{43}$ Ibid, 128.

${ }^{44}$ Ibid.

${ }^{45}$ Ibid, 129. 
dari ketritunggalan Allah terpelihara melalui koinonia dan tema perichoresis merupakan perpanjangan dari motif pembentukan komunitas. ${ }^{46}$ Arti asli dari perichoresis adalah "saling berkelindan" (mutual indweling) dan arti metafora untuk perichoresis ini adalah dansa atau tarian ilahi. ${ }^{47}$

Partisipasi kita dalam kehidupan Allah menentukan partisipasi kita dalam orang lain. Hal yang terkait dengan ini adalah gagasan "penerimaan", yang berarti "saya mengundang yang lain untuk berada di rumah dengan saya". ${ }^{48}$

Bagi Pembroke, relasionalitas menjadi istilah penting ketika berbicara tentang persekutuan Allah Tritunggal. Setiap pribadi akan menemukan dirinya dalam relasi dengan yang lain, sebab itu relasionalitas tidak sekadar menunjukkan adanya hubungan atau pun ikatan, tetapi eksistensi berkelanjutan dari setiap pribadi yang hanya dapat terjadi dalam persekutuan.

Teolog kedua, Catherine Mowry LaCugna, lebih fokus pada persekutuan antara Allah Tritunggal dengan manusia, sebagai satu-satunya cara untuk memahami konsep "relasi" dengan yang lain (baca: orang asing). Tesis LaCugna itu didasarkan pada kenyataan bahwa Tuhan berelasi dengan kita-yang merupakan karakter kepribadian Allah—sebagai ekspresi sempurna dari keberadaan Allah sebagai Tuhan. ${ }^{49}$ Penekanan pada intensionalitas dengan yang lain merupakan pusat usulan struktur trinitarian LaCugna. Ia menegaskan perlunya orientasi etis kepada orang lain sebagai dasar tindakan manusia yang bersumber dari tindakan Allah. Seseorang adalah inklusif, bebas, dan agen relasional. $^{50}$

Bagi LaCugna, relasi perichoresis Allah adalah relasi yang aktif, gembira, dinamis, dan vital dengan apa yang di luar diri-Nya dalam ruang waktu, sejarah dan kepribadian. Allah yang adalah kasih "tumpah" atas apa yang lain dari diri-Nya, yang melahirkan penciptaan dan sejarah. Allah yang adalah kasih tidak "terkunci" dalam 'isolasi ' cinta akan diri-Nya. Oleh karena itu, ajaran Allah Tritunggal pada dasarnya adalah tata bahasa dari Tuhan yang berada bersama dengan yang lain dari diri-Nya. ${ }^{51}$ LaCugna berkata:

"A person is thus not an individual but an open and ecstatic reality, referrend to others for his or her existence. The actualization of personhood takes place in self-transcendence, the movement of freedom toward communion with others. ${ }^{52}$

Jadi, keberadaan kita ditentukan oleh realitas terbuka kepada yang lain dari kita dalam sebuah persekutuan.

\footnotetext{
${ }^{46}$ Neil Francis Pembroke, The Art of Listening: Dialogue, Shame, and Pastoral Care (Grand Rapids: Wm. B. Eerdmans, 2002), 21.

${ }^{47}$ Pamela Cooper-White, Braided Selves, Dancing Partners Trinitarian Theology and the Use of the Self in Pastoral Care and Counseling (Oregon: Cascada Books, 2011), 120.

${ }^{48}$ Pembroke, The Art of Listening: Dialogue, Shame, and Pastoral Care, 21.

${ }^{49}$ Catherine LaCugna Mowry, God for Us: The Trinity and Christian Life (San Fransisco: Harper Collins, 1991), 305.

50 Ibid, 259.

${ }^{51}$ Ibid.

52 Ibid, 260.
} 
Menurut penulis, pendapat kedua teolog tentang strukur Allah Tritunggal di atas saling melengkapi. Jika Pembroke menekankan aspek perichoresis sebagai persekutuan yang melibatkan orang lain, maka LaCugna menekankan persekutuan yang terjadi melalui relasi dengan orang lain tanpa kekerasan atau hierarkisme. Pembroke menjadikan istilah relasionalitas dengan yang lain sebagai istilah penting dalam struktur Trinitarian dan LaCugna menjadikan istilah intensionalitas dengan yang lain sebagai pusat struktur Trinitarian.

Pemahaman kedua teolog di atas berangkat dari relasi dan persekutuan Allah Tritunggal yang dalam tiga Pribadi berbeda tetapi menerima satu dengan yang lain yang mempunyai implikasi sosial, yaitu praktik penerimaan kepada yang berbeda atau asing pada dirinya.

Dalam ajaran Debata Tiga Batu Tungku, perbedaan Pribadi Debata terletak pada pekerjaan dan peranan masing-masing, tetapi peranan dan pekerjaan itu saling melengkapi seperti yang bisa dipahami dari nama Pribadi: To Metampa (Mencipta), To Mepasalama' atau To Memana' (Menyelamatkan), dan To Meolaam (menyertai dan membimbing). Dengan demikian, kesatuan Debata adalah kesatuan dalam perbedaan, sehingga bisa berdialog dengan ajaran Allah Tritunggal. Dialog tersebut penting, karena penulis memahami bahwa ajaran Debata Tiga Batu Tungku juga tidak terhindar dari paham Allah Tritunggal modalisme seperti dijelaskan sebelumnya. Paham tersebut muncul secara khusus pada peranan Debata To Mepasalama' atau To Memana'.

Pada mulanya, praktik Debata To Mepasalama' atau To Memana' menerima orang asing berbeda dengan praktik pribadi Debata pertama dan ketiga. Pribadi Debata kedua mengasihi To Salu sedangkan orang asing tidak. Pribadi Debata pertama dan ketiga mengasihi semua orang. Fungsi ajaran Allah Tritunggal dalam kekristenan adalah "menerangi" atau berdialog serta memberi masukan kepada ajaran Debata Tiga Batu Tungku bahwa Sang Bapa, Sang Anak dan Roh Kudus tidak pernah bekerja sendiri-sendiri.

Hal tersebut di atas ditunjukkan juga oleh Alkitab, misalnya dalam Injil Matius 3: 16-17 tentang peristiwa Yesus dibaptis: "Sesudah dibaptis, Yesus segera keluar dari air dan pada waktu itu juga langit terbuka dan Ia melihat Roh Allah seperti burung merpati turun ke atas-Nya. Lalu terdengarlah suara dari Sorga yang mengatakan: "Inilah Anak-Ku yang Kukasihi, kepada-Nyalah Aku berkenan."

"Jalan masuk" ajaran Allah Tritunggal berdialog dengan ajaran Debata Tiga Batu Tungku adalah adanya Tarian Debata, mangnganda' atau mebajo sebagai simbol persekutuan Debata Tiga Batu Tungku dalam perbedaan peran atau fungsi. Para penari (To Mangnganda') melakonkan gerakan-gerakan yang penuh arti di bawah pohon barana (beringin) yang diiringi oleh padalim (gendang tarian di Mamasa). Tangan para penari yang terdiri atas tiga orang harus dalam posisi berpegangan dan tidak boleh dilepaskan. Para penari bisa kerasukan dan, konon, pernah terjadi bahwa para penari terangkat ke 
atas dahan pohon barana' sebagai efek dari kesatuan itu. Kesatuan Debata Tiga Batu Tungku dalam simbol tarian, berkaitan dengan perichoresis yang juga digunakan oleh Johannes Damascenus, seorang bapa gereja Timur, untuk menggambarkan sifat dari persekutuan Bapa, Putera dan Roh Kudus. ${ }^{53}$

Menurut LaCugna, perichoresis bagaikan koreografi. Koreografi adalah seni tari yang bertugas untuk mencipta gerakan-gerakan agar dapat ditampilkan sebagai suatu kesatuan yang menarik untuk dilihat. ${ }^{54}$ Menurut Joas Adiprasetya, adalah mungkin bagi ciptaan untuk berpartisipasi dalam perichoresis Allah Tritunggal berdasarkan energi merangkul Kristus. Di dalam Dia kita menemukan kesatuan perichoretik dan hipostatik dari ilahi dan sifat manusia. ${ }^{55}$

Mereka yang melakonkan tarian akan membentuk gerakan yang simetris dan tetap memperhatikan keseimbangan gerakan di antara mereka. Setiap pasangan penari akan selalu bersama-sama untuk membentuk gerakan-gerakan tersebut sehingga tidak ada yang bisa diam, tetapi terus bergerak. Gerakan yang indah tidak akan terjadi jika salah satu pasangan tidak ikut bergerak ataupun jika tidak ada ruang gerak di antara mereka. Indahnya tarian menandakan kesatuan di antara mereka dan sekaligus tetap adanya penghargaan terhadap pribadi masing-masing. Menurut LaCugna, tidak ada yang disebut pemimpin dan pengikut. ${ }^{56}$ Setiap penari mempunyai peran yang sama untuk terus bergerak dan saling memberi dan menerima.

Gerakan kasih yang melingkar tidak sekadar menggambarkan adanya hubungan satu dengan yang lain antara Bapa, Anak, dan Roh Kudus, tetapi mereka hidup di dalam dan melalui yang lain. Jadi, mereka tidak sekadar menari dan membentuk gerakan, tetapi gerakan melingkar di antara mereka merupakan ungkapan kasih yang menghidupkan. Kasih di antara mereka membuat mereka tidak dapat melepaskan diri satu dengan yang lain, tetapi justru semakin bergairah untuk tetap bersama. Perichoresis hendak menggambarkan kesatuan yang mendalam antara Bapa, Anak, dan Roh Kudus, yang dapat tercipta karena masing-masing pihak memberi diri tanpa batas kepada yang lain dan bahkan kepada seluruh ciptaan.

Dalam Trinitarianisme Timur, Gereja Ortodoks memahami tiga Pribadi (Bapa, Anak, Roh) sebagai titik tolak pemahaman mereka terhadap Allah Tritunggal dalam kesamaan hakikat masing-masing. Bapa tidak berasal atau dilahirkan (ungenerated, unpreceded), Anak dilahirkan (generated), sedangkan Roh Kudus adalah proses yang berlanjut (proceeded) dari Bapa. Roh Kudus merupakan pengikat persekutuan atau kasih

\footnotetext{
${ }^{53}$ Joy Ann McDougall, "The Return of Trinitarian Praxis", 186.

${ }^{54}$ Mowry, God for Us: The Trinity and Christian Life, 300.

${ }^{55}$ Joas Adiprasetya, "Towards a Perichoretic Theology of Religions" (Disertasi, Boston University, 2008), 192.

${ }^{56}$ Mowry, God for Us: The Trinity and Christian Life, 300.
} 
yang timbal-balik dari Allah dan Anak. Hunt mengatakan bahwa inilah gambaran perichoresis tentang hubungan Allah Tritunggal. ${ }^{57}$

Selanjutnya, Trinitarianisme dari sudut pandang gereja Barat yang diwakili oleh Augustinus dari Hippo, dalam karyanya De Trinitate, menekankan bahwa Allah adalah Bapa, Anak dan Roh Kudus. Allah Tritunggal adalah Allah atau Allah adalah Allah Tritunggal. ${ }^{58}$ Toar Banua Hutagalung berkata: "Augustinus juga memakai gambaran perichoresis dalam menerangkan hubungan ketiga pribadi Allah Tritunggal. Ia mengatakan bahwa masing-masing dalam masing-masing, semua dalam masing-masing, dan masing-masing dalam semua, semua dalam semua, dan semua adalah satu". ${ }^{9}$

Menurut LaCugna, dalam Allah Tritunggal, perichoresis berarti berada dalam satu dengan yang lain. Setiap pribadi ilahi tidak dapat tidak tertarik kepada yang lain, mengambil keberadaan yang lain, memiliki yang lain dalam diri salah satu pribadi, sementara dalam saat yang sama mencurahkan diri bagi pribadi yang lain. ${ }^{60}$

Sementara itu, menurut Jürgen Moltmann, istilah perichoresis berarti bahwa ketiga pribadi meninggalkan ruang bagi setiap pribadi untuk berdansa atau menari. Ketiga pribadi (Bapa, Anak dan Roh Kudus) secara sangat intim berada dalam satu sama lain, saling melakukan interpenetrasi, dan membentuk kesatuan dalam lingkaran kehidupan ilahi ketiga pribadi tersebut. Hutagalung menyimpulkan pemahaman Allah Tritunggal Moltmann sebagai "perichoresis" sebagai konsep yang dinamis dan juga konsep "interanimasi" sebagai suatu dialektika yang berlanjut dari pembedaan diri (selfdifferentiation) dan pemberian diri (self-giving). Keduanyalah yang membuat partikuralitas dan ke-liyan-an (otherness) dalam Allah Tritunggal dan kesatuan dari ketiga pribadi dengan satu sama lain. Atau dengan kata lain, perichoresis membuat perbedaan dalam Allah terikat bersama menjadi satu. Ketiga, tidak ada ide subordinasi di dalam konsep interanimasi. ${ }^{61}$

Dalam menghubungkan antara kesatuan dan perbedaan dalam Allah Tritunggal, Pembroke juga menggunakan istilah polyphony. Polyphony adalah istilah teknis musikal berkenaan dengan dimainkannya sejumlah nada secara bersamaan tanpa ada nada yang dominan. ${ }^{62}$ Apabila kesatuan dan perbedaan dianalogikan sebagai nada-nada yang dimainkan agar menghasilkan ritme yang indah untuk didengar, maka itu berarti, ritme

${ }^{57}$ Anne Hunt, Trinity: Nexus of The Mysteries of Christian Faith (New York: Orbis Books, 2005), 19.

${ }^{58}$ Leonardo Boff, Trinity and Society (Maryknoll, New York: Orbis Books, 1988), 55.

59 Toar Banua Hutagalung, "Berpartisipasi Dalam Persekutuan Trinitarian Melalui Bersedekah: Sebuah Kajian Teologis Dan Filosofis Terhadap Praktik Bersedekah Dengan Basis Relasionalitas" (Skripsi, STT Jakarta, 2010), 55.

${ }^{60}$ Mowry, God for Us: The Trinity and Christian Life, 271.

${ }^{61}$ Hutagalung, "Berpartisipasi Dalam Persekutuan Trinitarian Melalui Bersedekah: Sebuah Kajian Teologis Dan Filosofis Terhadap Praktik Bersedekah Dengan Basis Relasionalitas,” 59.

${ }^{62}$ Neil Francis Pembroke, "Trinity, Polyphony and Pastoral Relationship," The Journal of Pastoral Care \& Counseling 58, no. 4 (2004): 352. 
tidak akan tercipta jika yang dimainkan hanya salah satu saja. Dalam polyphony, nada yang terdengar lembut, keras, perlahan atau pun cepat, selama semuanya sesuai dengan ritme yang diharapkan, maka tidak ada yang salah dari nada-nada tersebut.

Polyphony di atas mempunyai kesamaan dengan tarian Debata (Mangnganda'). Padalim yang mengiringi tarian Debata yang dimainkan oleh sando ganda' (imam Gendang) mempunyai variasi bunyi yang berbeda tetapi menyatu. Ada tiga variasi bunyi dimaksud. Pertama mebali (bunyi asli gendang; yang dipukul adalah bagian tengan gendang; bunyi kedengaran seperti bass dalam seni suara). Kedua ditentem (bunyi dari bagian pinggir gendang; yang dimainkan adalah bagian pinggir gendang; bunyi seperti sopran dalam seni suara). Ketiga, dipasikore (bunyi yang keluar dari pemukul gendang yaitu dua balok-balok kecil dari kayu keras yang telah dihaluskan; pemain gendang membenturkan kedua pemukul tersebut sehingga mengeluarkan bunyi menyerupai tenor dalam seni suara). Bunyi-bunyi itu berbeda tetapi saling melengkapi. Itu semua adalah gambaran tentang Debata Tiga Batu Tungku yang bersatu-padu dalam perbedaan.

Mangnganda' memberi makna bagi ajaran Allah Tritunggal bahwa kesatuan dan perbedaan Bapa, Anak, dan Roh Kudus bagaikan kesatuan jenis-jenis suara dalam seni suara (sopran, tenor dan bass). Jadi, kesatuan tidaklah mengaburkan eksistensi dari setiap pribadi Allah Tritunggal, justru memunculkan keseimbangan antara pribadi dan relasionalitas.

\section{Kesimpulan}

Ada beberapa kesimpulan yang penting setelah pembahasan sebelumnya, sebagai berikut: Pertama, dalam ajaran Allah Tritunggal, Allah sebagai Bapa yang diyakini memelihara dan memberikan kasih seorang Bapa sejati yang sangat mesra, begitu penyayang dalam mencipta dan memelihara ciptaan-Nya. Kasih Bapa Sorgawi tidak pernah sama dengan kasih para bapa (para bapa atau para ayah) dunia ini. Oleh karena itu, Ia adalah Bapa yang sempurna. Demikian juga dalam ajaran Debata Tiga Batu Tungku, To Salu mengakui bahwa Debata tersebut melampaui fungsi debata-debata lainnya, karena Debata To Metampa adalah yang Ambe Ponno Pa'kamase (Bapa Penuh Kasih) dan mutokei pairam (memegang keadilan dan ketegasan serta kedisiplinan dalam mengontrol kehidupan ciptaan-Nya). Ia berbeda dengan debata kaliane (dewa orang asing) seperti anitu, poppa', bombo, topela'duk dan lain-lain yang selalu mengganggu To Salu melalui mimpi dan dalam kehidupan nyata.

Kedua, Alkitab menyatakan bahwa Anak merupakan Anak sulung Allah dari semua anak-Putra; dimaksudkan bahwa Anak pun merupakan "Sahabat Sejati" yang rela mengorbankan nyawa-Nya dan tidak menyayangkan-nya sama sekali supaya manusia dapat diterima sebagai anak-Putra. Demikian juga dalam kepercayaan To Salu, Debata To Mepasalama' atau To Memana' dalam Alu' Todolo memang tidak dipahami sebagai yang mati di kayu salib dan seterusnya seperti yang dialami Putra. Di sinilah letak 
perbedaannya. Tetapi To Salu juga mempercayai adanya inkarnasi (bahasa setempat: membali). Debata Tometampa membali rupatau (Allah Pencipta berinkarnasi menjadi manusia).

Ketiga, Roh Kudus adalah Allah Pembimbing, Pendamping, Penolong, Penyerta, dan Penghibur yang tidak terlihat, namun berada dalam hati setiap manusia yang mengaku bahwa Yesus Kristus adalah Tuhan dan hidup di dalam-Nya. Roh Kudus bukanlah kebijaksanaan (pikiran) tertinggi dari seluruh alam jagat kosmik. Roh Kudus bukanlah seorang tokoh pendiri suatu agama baru. Roh Kudus tidak pernah berbau hal yang mistik. Memang benar bahwa Allah itu maha kuasa, tetapi Roh Kudus itu bukan sekadar kuasa atau kekuatan, tetapi Roh Kudus adalah pribadi Allah, sebab Allah itu Roh. Dengan demikian, Roh Kudus adalah Pribadi Allah itu sendiri dan merupakan bagian yang tidak terpisahkan dari Allah. Dalam kepercayaan To Salu, Debata To Meolaam, yang disebut bersama dengan Debata To Metampa sebagai Debata Langi' (dewa langit) dan hadir dalam simbol tiga batu tungku, juga berperan sebagai penyerta dan pemberi petunjuk atau wahyu kepada To Salu. Orang yang telah menerima Debata To Mepasalama' atau To Metampa' akan menerima hikmat dan kemampuan melakukan atau menjalankan ritus Alu’ Todolo yang terangkum dalam Pemali Appa Randanna.

\section{Referensi}

Adiprasetya, Joas. “Towards a Perichoretic Theology of Religions.” Disertasi, Boston University, 2008.

Armour, Ellen T, and et.al. "God." In Constructive Theology, edited by Serene Jones and Paul Lakeland. Minneapolis: Fortress Press, 2005.

Banawiratma, J.B. Agenda Pastoral Transformatif. Yogyakarta: Kanisius, 2002.

Barth, C. Theologia Perjanjian Lama 1. Jakarta: BPK Gunung Mulia, 1970.

Bevans, Stephen B. Models of Contextual Theology, Revised and Expanded Edition. New York: Orbis Books, 2002.

Boff, Leonardo. Trinity and Society. Maryknoll, New York: Orbis Books, 1988.

Buijs, Kees. Powers of Blessing From The Wilderness and From Heaven: Structure and Transformation in The Religion of The Toraja in Mamasa Area of South Sulawesi. Leiden: KITLV Press, 2006.

Cooper-White, Pamela. Braided Selves, Dancing Partners Trinitarian Theology and the Use of the Self in Pastoral Care and Counseling. Oregon: Cascada Books, 2011.

Green, Clifford, ed. Karl Barth: Teolog Kemerdekaan. Jakarta: BPK Gunung Mulia, 1997. Hunt, Anne. Trinity: Nexus of The Mysteries of Christian Faith. New York: Orbis Books, 2005.

Hutagalung, Toar Banua. “Berpartisipasi Dalam Persekutuan Trinitarian Melalui Bersedekah: Sebuah Kajian Teologis Dan Filosofis Terhadap Praktik Bersedekah Dengan Basis Relasionalitas." Skripsi, STT Jakarta, 2010.

Lane, Tony. Runtut Pijar: Sejarah Pemikiran Kristiani. Jakarta: BPK Gunung Mulia, 1993. Lee, Jung Young. The Trinity in Asian Pespective. Nashville: Abingdon Press, 1996. 
Matanga', Jidon. “Doti Dan Kekristenan.” Pembinaan PPGTM Klasis Makassar. Makassar, 1988.

Mowry, Catherine LaCugna. God for Us: The Trinity and Christian Life. San Fransisco: Harper Collins, 1991.

Pappalan, P. “Ada' Tomalillim.” Ceramah GTM-Klasis Bambang Hulu. Mamasa, 1976.

———. "Ajaran Allah Tritunggal Geleijnse." Pembinaan Majelis Gereja Jemaat Saludengen. Mambi, 1969.

_—_. "Dapo' Anna Debata." Pembinaan Majelis Gereja Saludengen. Mambi, 1976.

- — - "To Pusa: To Bulim Anna To Mangnganga." Pembinaan GTM Klasis Malatiro. Mamasa, 1999.

Pembroke, Neil Francis. The Art of Listening: Dialogue, Shame, and Pastoral Care. Grand Rapids: Wm. B. Eerdmans, 2002.

- _ - "Trinity, Polyphony and Pastoral Relationship." The Journal of Pastoral Care \& Counseling 58, no. 4 (2004).

Singgih, Emanuel Gerrit. Berteologi Dalam Konteks: Pemikiran-Pemikiran Mengenai Kontekstualisasi Di Indonesia. Yogyakarta: Kanisius, 2000.

Timo, Ebenhaizer I. Nuban. Allah Yang Mengulang Diri-Nya Tiga Kali: Suatu Pertimbangan Bagi Dogmatika Kontekstual Indonesia. Salatiga: Satya Wacana University Press, 2013.

Wawancara:

Ambe Nongkam. "Wawancara Oleh Penulis, Ulumambi," October 18, 2015.

Apul. “Debata Tomemana." Ceramah PPGTM Klasis Bambang Hilir. Mambi, 1999.

Apul, Sando. "Wawancara Oleh Penulis, Mambi," May 15, 2014.

Pabolla. "Wawancara Oleh Penulis, Mamasa," April 7, 2015.

Patu', Sando. "Wawancara Oleh Penulis, Salutabang," 2014.

Yuliance. "Wawancara Oleh Penulis, Rantelemo," June 12, 2018. 